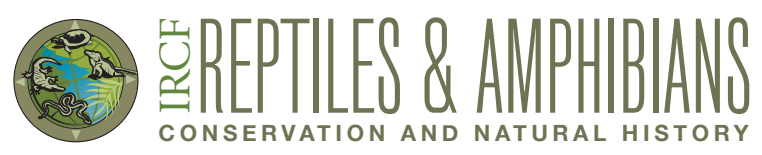

\title{
New Locality Records of Leschenault's Snake Eye, Ophisops leschenaultii (Sauria: Lacertidae) (Milne-Edwards, 1829) from Telangana State, with Notes on the Species' Natural History
}

\author{
Gandla Chethan Kumar ${ }^{1}$, Chelmala Srinivasulu ${ }^{1,2}$, and Kante Krishna Prasad ${ }^{1}$
}

${ }^{1}$ Wildlife Biology \& Taxonomy Lab, Department of Zoology, University College of Science, Osmania University, Hyderabad, Telangana State 500007, India (g.chethankumar@gmail.com)

${ }^{2}$ Natural History Museum and Wildlife Biology \& Taxonomy Lab, Department of Zoology, University College of Science, Osmania University, Hyderabad, Telangana State 500007, India and Systematics, Ecology \& Conservation Laboratory, Zoo Outreach Organization (ZOO), Coimbatore, Tamil Nadu 641035, India

$\mathrm{T}$ The eight currently recognized species of snake-eyed lizards in the genus Ophisops (Lacertidae) range widely across southeastern Europe, northern Africa, and eastward into Asia as far as the Indian Subcontinent (Kyriazi et al. 2008). The genus has long been of scientific interest due to its astonishing phenotypic variability and resulting taxonomic complexity and instability (Arnold and Burton 1978; Arnold 1989, 2004). Biogeographic analyses and estimated times of divergence suggest a late Miocene diversification within the genus (Kyriazi et al. 2008). Although that phylogenetic study focused on the two Mediterranean species (O. elegans and $O$. occidentalis), one individual of $O$. jerdonii collected in India was included in the study. It showed a high degree of divergence from all other clades. Studies pertaining to the genus Ophisops in the Indian subcontinent, like those more broadly in Asia, are still in a nascent stage.

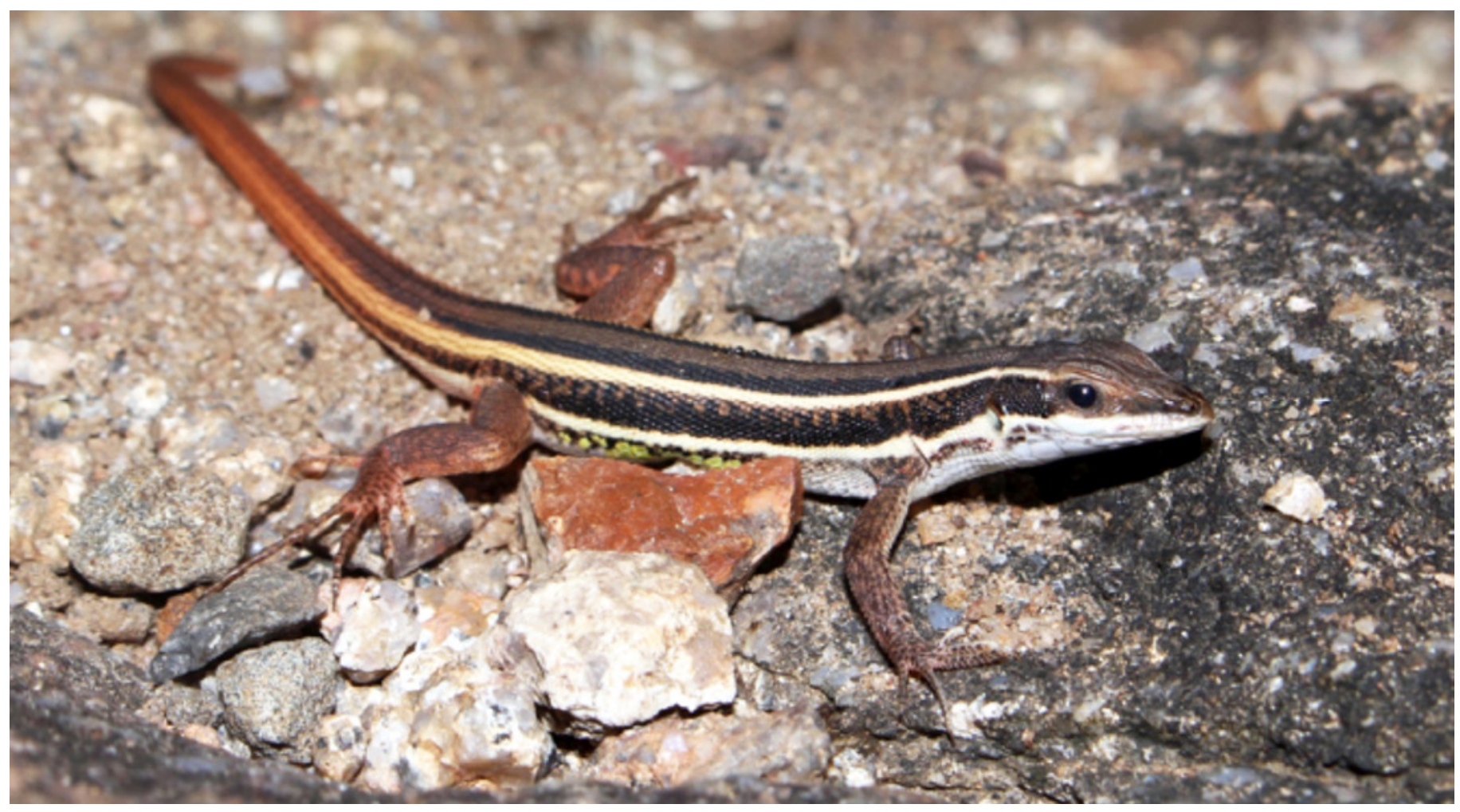

Fig. 1. Leschenault's Snake Eye, Ophisops leschenaultii (Milne-Edwards 1829) from the Kawal Tiger Reserve, Adilabad District, Telangana State, India. Photograph by Gandla Chethan Kumar. 
The Indian subcontinental endemic, Leschenault's Snake Eye (Ophisops leschenaultii ; Fig. 1), was originally described as Lacerta leschenaulti by Milne-Edwards in 1829 based on specimens collected along the Coromandel Coast. Subsequently, the generic allocation of this species has been debated. It was assigned to the genus Calosaura by Duméril and Bibron (1839), to Cabrita by Blanford (1870), and to Ophisops by Deraniyagala (1953, although he reverted to Cabrita in 1971). However, beginning with Das (1996), the species has been placed consistently within Ophisops. In Sri Lanka, an endemic subspecies (O. l. lankae) is largely restricted to the northern and eastern dry grasslands at elevations ranging between 500 and $1,500 \mathrm{~m}$ asl.

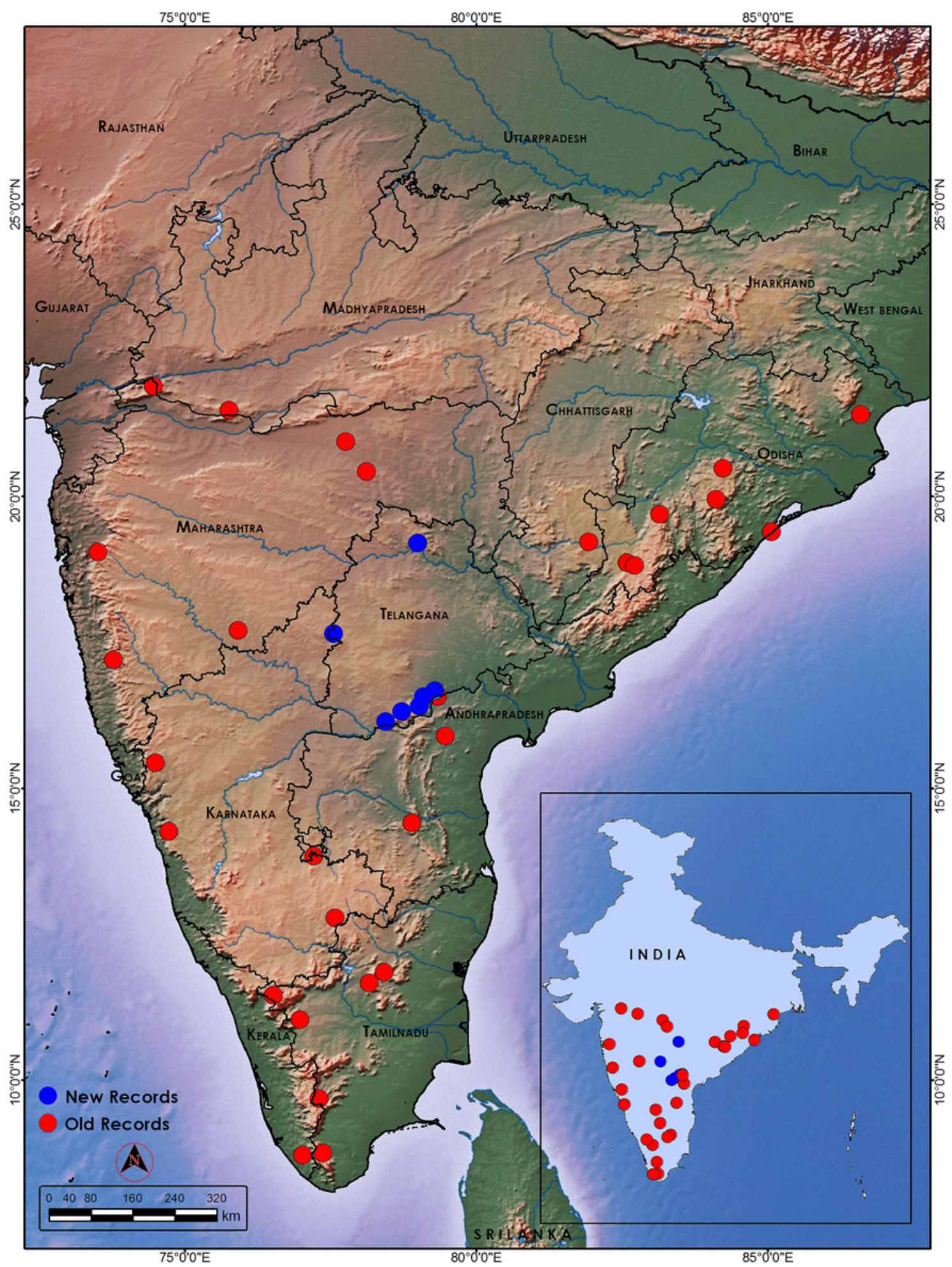

Fig. 2. Currently known distribution of Leschenault's Snake Eye (Ophisops leschenaultii) in India. Red dots indicate previously recorded localities, blue dots mark the new records from Telangana State. 
Although the Eastern Ghats contribute significantly to both species richness and endemicity of the Indian Subcontinent, these hills and Telangana State in general are underrepresented and continue to receive less attention for study and conservation compared to the relatively betterknown Western Ghats (Srinivasulu and Das 2008; Chethan Kumar and Srinivasulu, unpublished data). During efforts to document the herpetofauna in the districts of Adilabad, Mahbubnagar, Medak, Nagarkurnool, and Nalgonda of Telangana State in mid-September 2015, we recorded seven hitherto unreported localities for $O$. leschenaultii (Fig. 2): (1) Kawal $\left(19.18996^{\circ} \mathrm{N} 78.993957^{\circ} \mathrm{E}\right.$; elevation $270 \mathrm{~m}$ ) in Adilabad District; (2-4) Achampet Lodhi $\left(16.301684^{\circ} \mathrm{N} 78.720513^{\circ} \mathrm{E}\right.$; elevation $\left.79 \mathrm{~m}\right)$, Mallela Thirtham $\left(16.266940^{\circ} \mathrm{N} 78.857914^{\circ} \mathrm{E}\right.$; elevation $\left.694 \mathrm{~m}\right)$, and Mollachintapally $\left(16.133200^{\circ} \mathrm{N} 78.441257^{\circ} \mathrm{E}\right.$; elevation $498 \mathrm{~m}$ ), all in Mahbubnagar District; (5) Govindapur Thanda $\left(17.641292^{\circ} \mathrm{N} 77.54998^{\circ} \mathrm{E}\right.$; elevation $\left.622 \mathrm{~m}\right)$ in Medak District; (6) Udimilla $\left(16.394^{\circ} \mathrm{N} 79.02208^{\circ} \mathrm{E}\right.$; elevation $466 \mathrm{~m}$ ) in Nagarkurnool District; and (7) Vizag Colony $\left(16.563^{\circ} \mathrm{N} 79.09659^{\circ} \mathrm{E}\right.$; elevation $\left.208 \mathrm{~m}\right)$ in Nalgonda District.

Until 2 June 2014, Telangana was considered part of the state of Andhra Pradesh, so historical records of the species attributed to Andhra Pradesh (Sharma 1971; Murthy 1986; Sanyal et al. 1993; Srinivasulu and Das 2008; Srinivasulu et al. 2014) include records that now apply to Telangana. Previous records from Guntur, Kadapa, and Kurnool Districts remain in Andhra Pradesh, whereas those from Vijayapuri in Nalgonda District are in Telangana.

Ophisops leschenaultii prefers open areas in scrub and dry deciduous forest terrain, where it is largely restricted to rocky habitats (Champion and Seth 1969; Srinivasulu et al. 2014). In Kawal (Adilabad District), we observed four individuals moving along a rocky streambed about $50 \mathrm{~m}$ from a seasonal stream. The predominant tree species in the area are Borassus flabellifer, Ficus benghalensis, Azadirachta indica, Holoptelea integrifolia, Tectona grandis, Bamboosa arundinace, Tectona grandis, Terminalia arjuna, Terminalia tomentosa, and Acacia nilotica, Shrub species include Prosopis juliflora, Jatropha glandulifera, and Vitex negundo. Other lizards commonly encountered during the study were the Indian Garden Lizard, Calotes versicolor complex (Daudin 1802) and Blanford's Rock Agama, Psammophilus blanfordanus (Stoliczka 1871). In Mahbubnagar and Nalgonda Districts, we found $O$. leschenaultii to be sympatric with the near-threatened Sharma's Skink, Eutropis nagarjunensis (Sharma 1969).

Leschenault's Snake Eye is extremely fleet of foot and moves so rapidly that tracking its movements is difficult (Daniel 2002). The species is diurnally active and is known to lay as many as seven eggs (Daniel 2002; Srinivaulu et al. 2014). The main threats to this species are constant stone quarrying and forest fires, which degrade or destroy the rocky microhabitats and result in considerable mortality (Srinivauslu et al. 2014). The species is assumed to be uncommon in occurrence, but data originating from the recent field surveys in the state suggests that it might have a wider range than currently recognized. In addition, molecular studies are needed to clearly establish the status of all currently recognized species in the genus Ophisops on the Indian Subcontinent.

\section{Acknowledgements}

We thank the Telangana Forest Department, especially P.K. Sharma, Principle Chief Conservator of Forest and Chief Wildlife Warden, for granting permission to conduct our surveys. G. Ravinder, Divisional Forest Officer, and the field staff of the Kawal Tiger Reserve provided constant support in the field and logistical support throughout the study period. We also thank the Head, Department of Zoology, Osmania University, Hyderabad, for providing necessary facilities. We acknowledge UGC, New Delhi; DST-SERB, New Delhi; and UGC-DRS-SAP III, Department of Zoology, Osmania University for research grants.

\section{Literature Cited}

Arnold, E.N. 1989. Towards a phylogeny and biogeography of the Lacertidae: Relationships within an Old-World family of lizards derived from morphology. Bulletin of British Museum (Natural History) Zoology 55: 209-257.

Arnold, E.N. 2004. Overview of morphological evolution and radiation in the Lacertidae, pp. 11-36. In: V. Perez-Mellado, N. Riera, and A. Perera (eds.), The Biology of Lacertid Lizards. Evolutionary and Ecological Perspectives. Institut Menorquı d'Estudis, Recerca, Menorca.

Arnold, E.N. and J.A. Burton. 1978. A Field Guide to the Reptiles and Amphibians of Britain and Europe. Collins, London, UK.

Blanford, W.T. 1870. Notes on some Reptilia and Amphibia from central India. Proceedings of the Asiatic Society of Bengal, Calcutta 1870: 254-257.

Daniel, J.C. 2002. The Book of Indian Reptiles and Amphibians. Bombay Natural History Society, Oxford University Press, Oxford, UK.

Das, I. 1996. Biogeography of the Reptiles of South Asia. Krieger Publishing Co., Malabar, Florida.

Deraniyagala, P.E.P. 1953. A Coloured Atlas of Some Vertebrates from Ceylon. Volume 2. Tetrapod Reptilia. Government Press, Colombo, Ceylon (= Sri Lanka).

Deraniyagala, P.E.P. 1971. A new lizard from Ceylon. Spolia Zeylanica 32: 103-105.

Duméril, A.M.C. and G. Bibron. 1839. Erpétologie Générale ou Histoire Naturelle Complète des Reptiles. Tome Cinquième. Librairie Encyclopédique de Roret, Paris.

Kyriazi, P., N. Poulakakis, A. Parmakelis, P.A. Crochet, J. Moravec, N. RastegarPouyani, C.S. Tsigenopoulos, A. Magoulas, M. Mylonas, and P. Lymberakis. 2008. Mitochondrial DNA reveals the genealogical history of the snake-eyed lizards (Ophisops elegans and O. occidentalis) (Sauria: Lacertidae) Molecular Phylogenetics and Evolution 49: 795-805.

Murthy, T.S.N. 1986. Lizards of Kurnool District. Bulletin of the Maryland Herpetological Society 22:134-143.

Sanyal, D.P., B. Dattagupta, and N.C. Gayen. 1993. Reptilia, pp. 1-63. In: A.K. Ghosh (ed.), Fauna of Andhra Pradesh, Part 1. (Reptilia, Amphibia, Fishes). Zoological Survey of India, Kolkata.

Sharma, R.C. 1971. The reptile fauna of the Nagarjunasagar Dam area (Andhra Pradesh, India). Records of the Zoological Survey of India 63: 77-93.

Sharma, R.C. 2002. The Fauna of India and the Adjacent Countries. Reptilia, Volume II Sauria. Zoological Survey of India, Kolkata.

Smith, M.A. 1935. The Fauna of British India, Including Ceylon and Burma. Reptilia and Amphibia. Vol. II. Sauria. Taylor and Francis, London, UK. 
Srinivasulu, C. and I. Das 2008. The herpetofauna of Nallamala Hills, Eastern Ghats, India: An annotated checklist, with remarks on nomenclature, taxonomy, habitat use, adaptive types and biogeography. Asiatic Herpetological Research 11: 110-131.
Srinivasulu, C., B. Srinivasulu, and S. Molur. 2014. The Status and Distribution of Reptiles in the Western Ghats, India. Conservation Assessment and Management Plan (CAMP). Wildlife Information Laision Development Society, Coimbatore, Tamil Nadu. 